\title{
Sínjáró Volkswagen - a Kübelwagen Typ 82 sínautó
}

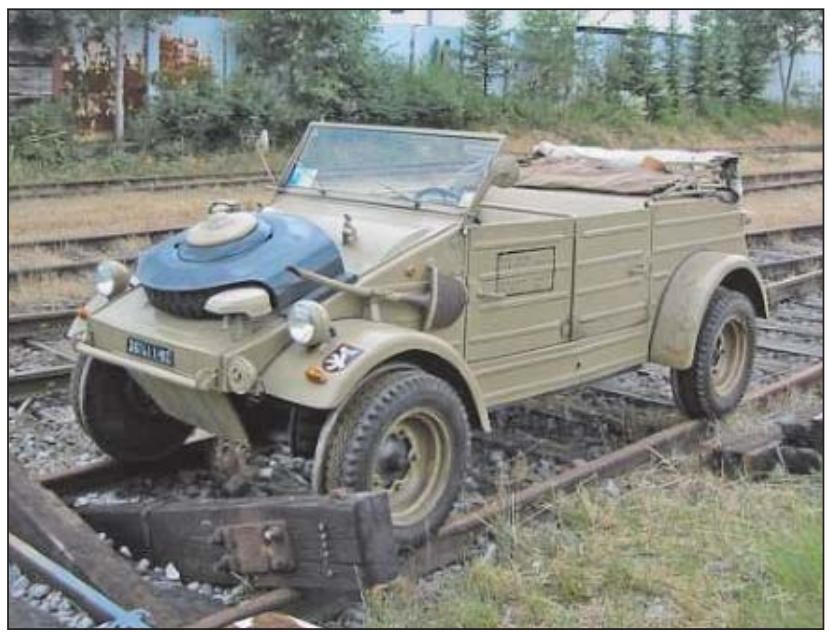

1. ábra. A Kübelwagen Typ 82 katonai terepjáró gépkocsi bázisán kialakított sínjáró Volkswagen

- gy háború általában rossz utak akaratlan, kényszerü használatát is jelenti. Ezért is szerelnek fel minden hadsereget a technika mindenkori állásának és az országok anyagi lehetőségének megfelelően, terepjáró járművekkel. Sok esetben azonban a terep adottságai az ilyen feladatokra legnagyobb gondossággal készített gép-

\section{2. ábra. A legegyszerübb sínüzem. A mocsaras talajon} lefektetett farönkökön halad a gépkocsi, gumiabroncs nélküli keréktárcsákkal

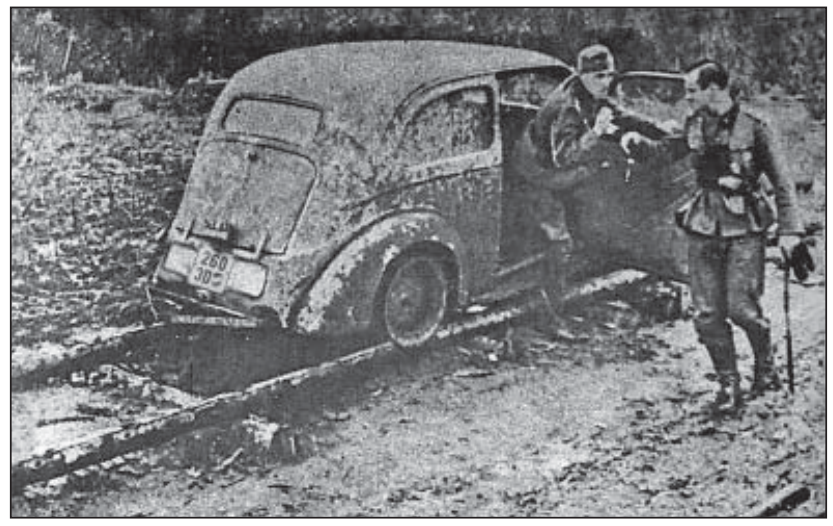

ÖSSZEFOGLALÁS: A Volkswagen katonai gépkocsikhoz gyártott „sínjáró szett" lényege az volt, hogy a gépkocsi a sínpályán is a saját, eredeti kerekén haladhasson. Valamennyi keréknél egy könnyü, mindössze $3 \mathrm{~mm}$ vastag, a külső szélén peremezett acéltárca biztosította, hogy a gumi futófelület a sín koszorúján maradjon. Az átszerelést két személy - kizárólag a gépkocsi tartozékaival -15 perc alatt el tudta végezni.

KULCSSZAVAK: német haderő, II. világháború, sínjáró Volkswagen, Kübelwagen Typ 82

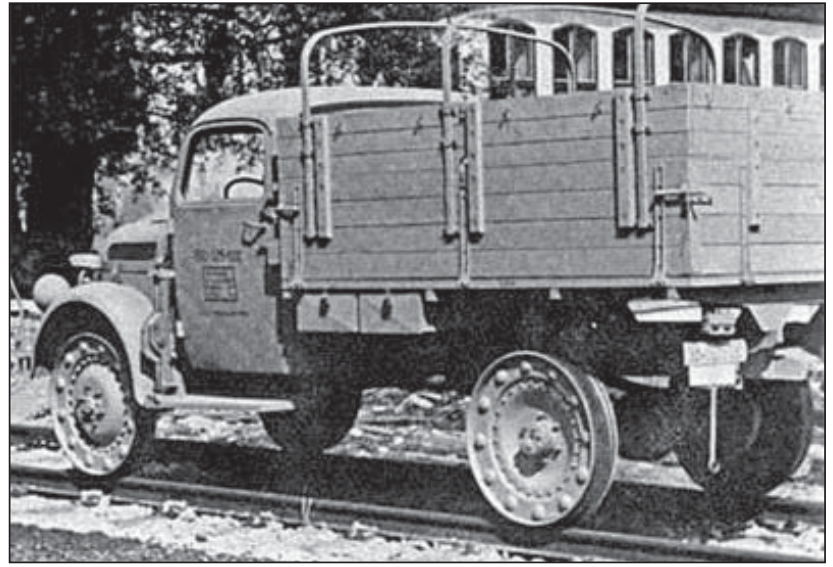

3. ábra. Steyr 1500-as gépkocsi sínüzemre átalakítva.

Az öntött koszorús kerekek súlya egy teherautónál nem jelentett problémát, azonban ezek, vagy a közúti kerekek a raktér egy részét elfoglalták

kocsik képességeit is meghaladják. Ilyenkor más megoldást kell keresni, ami nem ritkán az adott körzetben létező vasútvonal pályája lehet. Ez hosszú, egyenes, váltóktól mentes szakaszon egyszerűen a talpfákon haladást is jelentheti, ami minden kényelmetlensége és a járművet károsító hatása ellenére használható megoldás.

Egy adott sínpálya igénybevétele a vasútéhoz hasonló kerekekkel felszerelt közúti járművekkel, ugyancsak bevett gyakorlat volt a háborúk során. Ehhez persze a gépkocsit alkalmassá kellett tenni az ilyen üzemmódra. Erre a huszadik század háborúi során több megoldást is alkalmaztak. Általánosan elterjedt volt az eredetileg közúti jármű kerekeinek lecserélése öntött acélból készült, nyomkarimás kerekekre. Itt - különösen kisebb járművek esetében - komoly problémát jelentett a „vasúti” kerekek jelentős súlya. Egyetlen ilyen öntött kerék - annak méretétől függően 5-10 kg, nagyobb gépkocsi esetében $30-40 \mathrm{~kg}$ is lehetett.

Nyilvánvaló, hogy ezeknek szállítása, átszerelése egyaránt komoly terhet jelentett.

Mindezek tükrében különösen szellemes megoldás volt a Volkswagen katonai gépkocsikhoz gyártott „sínjáró szett". Ennek a megoldásnak a lényege az volt, hogy a gépkocsi a sínpályán is a saját, eredeti kerekén haladt. Valamennyi keréknél egy könnyű, mindössze $3 \mathrm{~mm}$ vastag, a külső szélén peremezett acéltárca biztosította, hogy a

ABSTRACT: The main feature of the 'rail walking set' manufactured for Volkswagen military cars was that the car moved on its original wheels, but on all wheels there was a $3 \mathrm{~mm}$ thick steel disc with a flange on its outer rim enabling the ribbon cover protector to remain on the rail head. Two persons were able to accomplish refitting within 15 minutes by the use of accessories of the car only.

KEY WORDS: German armed forces, World War II, Volkswagen road-rail vehicle, Kübelwagen Typ 82 


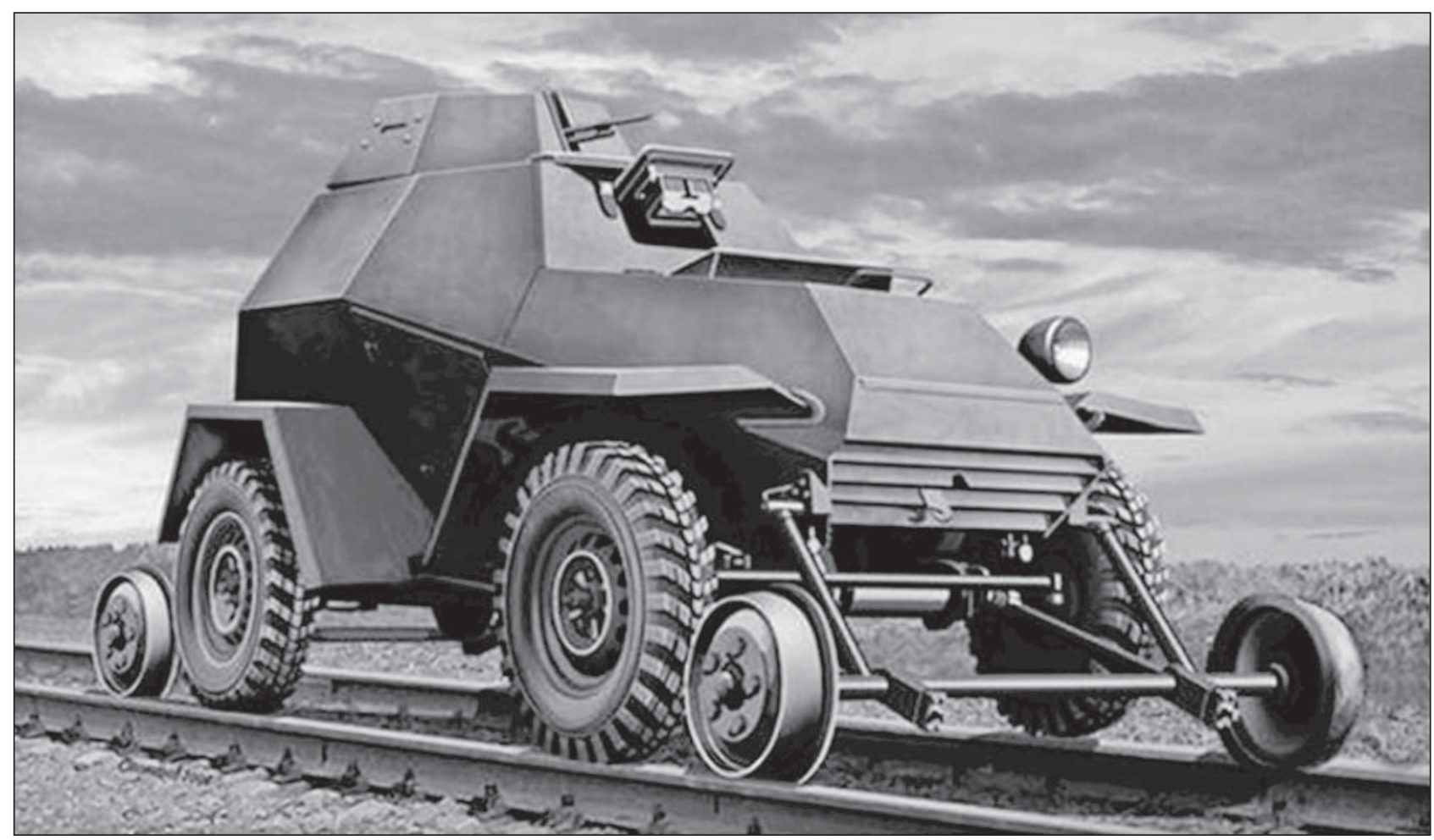

4. ábra. Az esetenkénti sínüzem másik lehetséges - a kerekek cseréjénél lényegesen praktikusabb megoldása - a szovjet BA-64 B páncélkocsinál. A négy öntött vasúti kerék közúti használat esetén felhajtható volt

gumi futófelület a sín koszorúján maradjon. A tárcsák súlya olyan kicsi volt, hogy a nem alvázas szerkezetű, hanem önhordó karosszériás VW Kübelwagen pótkereke alá málházva a gépkocsi üzemét semmilyen módon nem befolyásolta. Méretük pedig alig valamivel haladta meg az abroncs átmérőjét.

Az átszerelést két személy, csak a gépkocsi tartozékaival (emelő, csavarkulcs), kb. 15 perc alatt el tudta végezni. Ez pedig a következőképpen történt: a kerekeket egyenként leszerelték, majd a fékdobra ráhelyezték az acéltárcsát, amelyet három préselt körme segített megtartani, amíg a kereket fordított keréktárcsával ugyancsak a helyére tették. A rögzítéshez alkalmazott, az eredetinél hosszabb és peremmel ellátott csavarok a szett részét képezték. A müködtetést leíró szabályzat a sínre történő felhajtást lehetőség szerint olyan helyen javasolja, ahol a sín süllyesztett, és

5. ábra. A Volkswagen Kübelwagen Type 82 a málházott nyomtárcsákkal

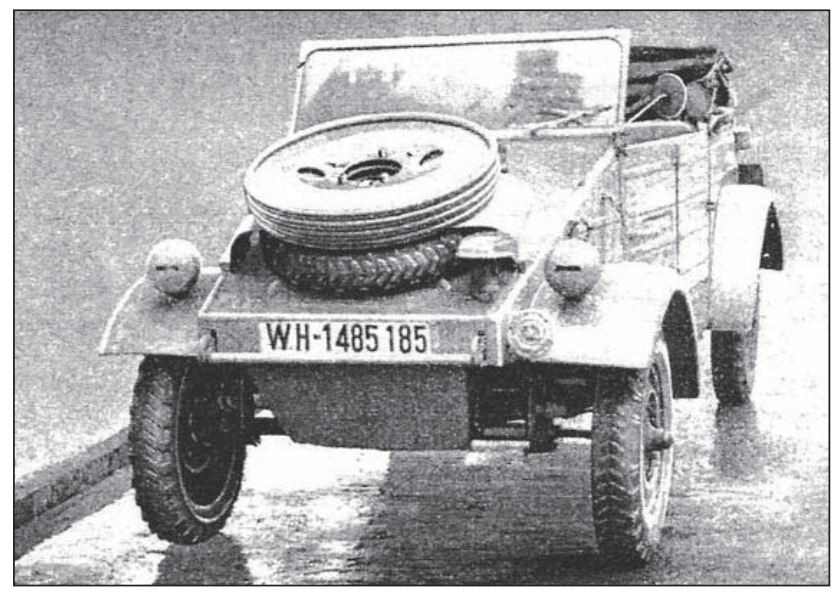

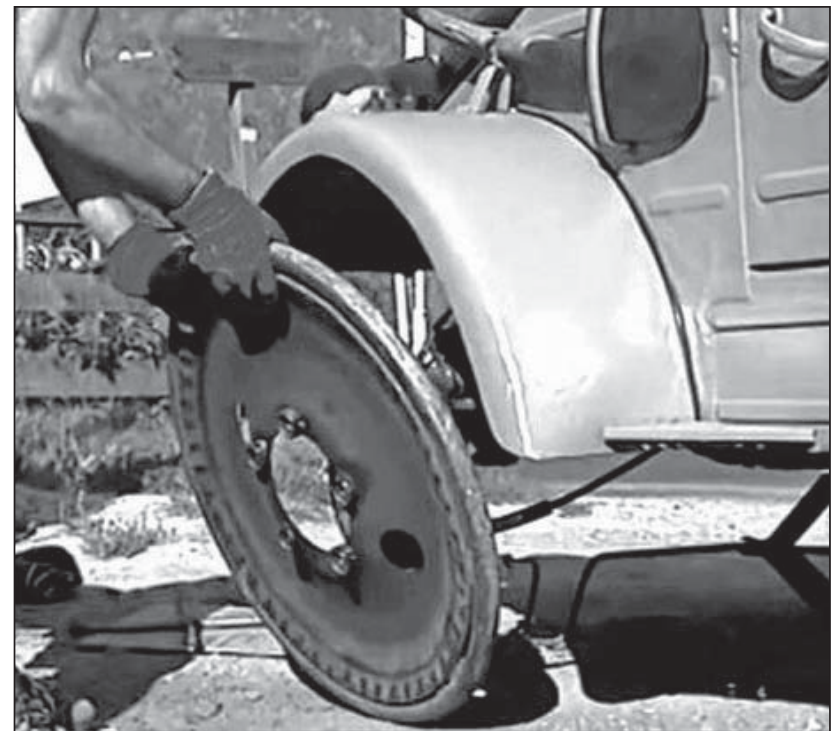

6. ábra. Az átszerelés első fázisa. A leszerelt kerekek helyére a tárcsát, majd arra a kifordított kereket szerelik fel

arra hátramenetben, először a hátsó, majd ezt követően az első kerekekkel kell ráállni.

A Kübelwagen hátsó kerekei lengőtengellyel kapcsolódtak a differenciálmühöz. Ez azt is jelentette, hogy a rugózáskor az íves elmozdulás miatt a hátsó kerekek nyomtávolsága a terheléstől, illetve a rugózás mértékétől függően változott. Ennek nyomán fennállhatott a veszély, hogy a két hátsó acéltárcsa egymástól a normál nyomtávnál kisebb vagy nagyobb távolsága esetén, a kerekek leugorhatnak a sínkoszorúról. Ezt oldalanként egy, a hosszanti vezető-lengőkarra, a tervezett terhelésnek megfelelő helyre szerelt ütközőelem akadályozta meg. 


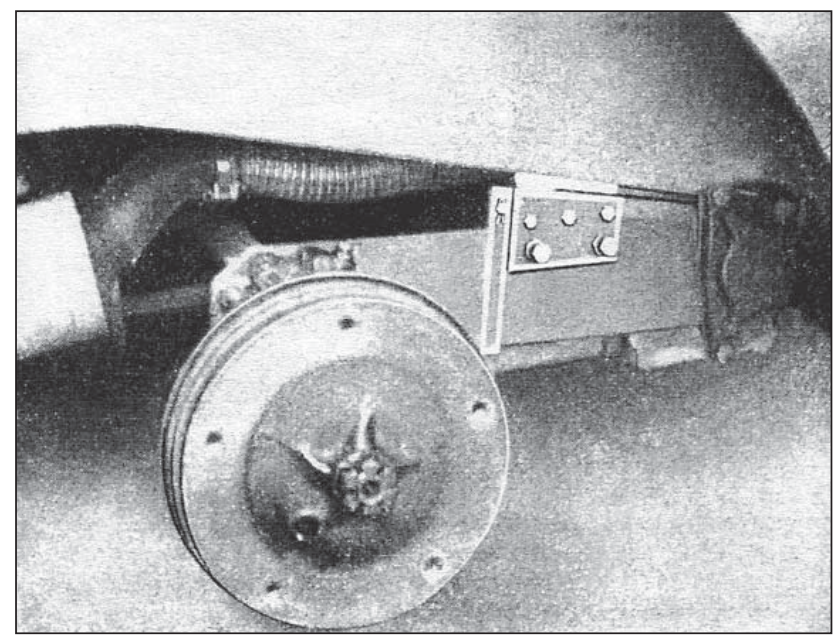

7. ábra. A hátsó kerék vezetését biztosító hosszanti lengőkarra rögzített, berugózást korlátozó ütköződarab

1. táblázat. A Kübelwagen Typ 82 sínjáró Volkswagen föbb adatai (S. Gy.)

\begin{tabular}{|l|c|}
\hline Hosszúság & $3740 \mathrm{~mm}$ \\
\hline Szélesség & $1600 \mathrm{~mm}$ \\
\hline Magasság & $1650 \mathrm{~mm}$ \\
\hline Szerkezeti tömeg & $725 \mathrm{~kg}$ \\
\hline Össztömeg & $1175 \mathrm{~kg}$ \\
\hline Hasznos teher & $450 \mathrm{~kg}$ \\
\hline Max. sebesség & $90 \mathrm{~km} / \mathrm{h}$ \\
\hline Hatótávolság & $440 \mathrm{~km}$ \\
\hline Eröforrás & $\begin{array}{r}4 \text { hengeres } 895 \mathrm{~cm}^{3}-\mathrm{es} \\
23,5 \mathrm{LE} 30001 / \mathrm{min}^{-}\end{array}$ \\
\hline Gyártott mennyiség & Type $62 / 82: 50435 \mathrm{db}$ \\
\hline
\end{tabular}

8. ábra. Az átszerelés után - a sínüzemre kész gépkocsi

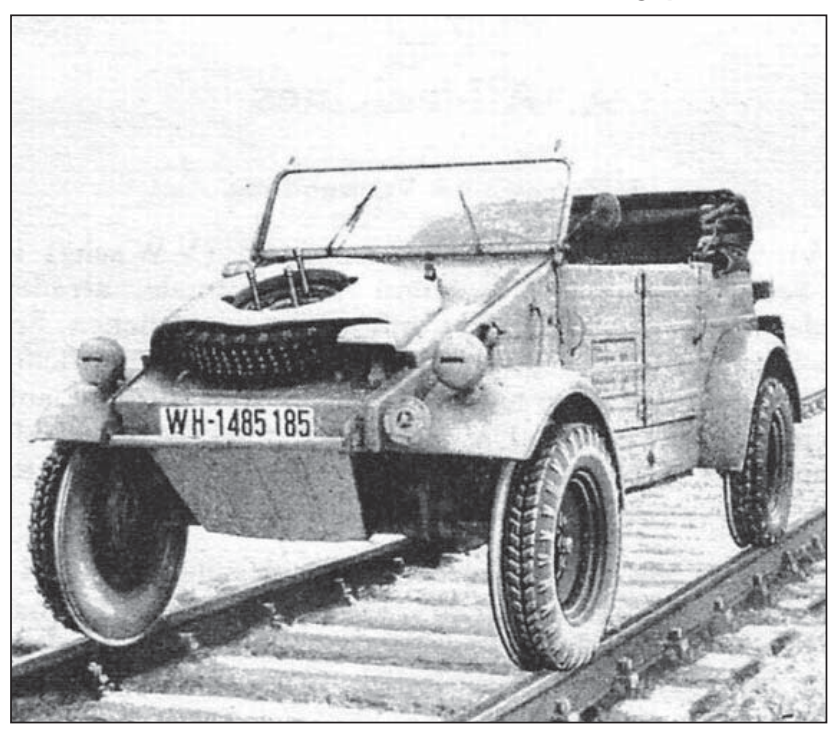

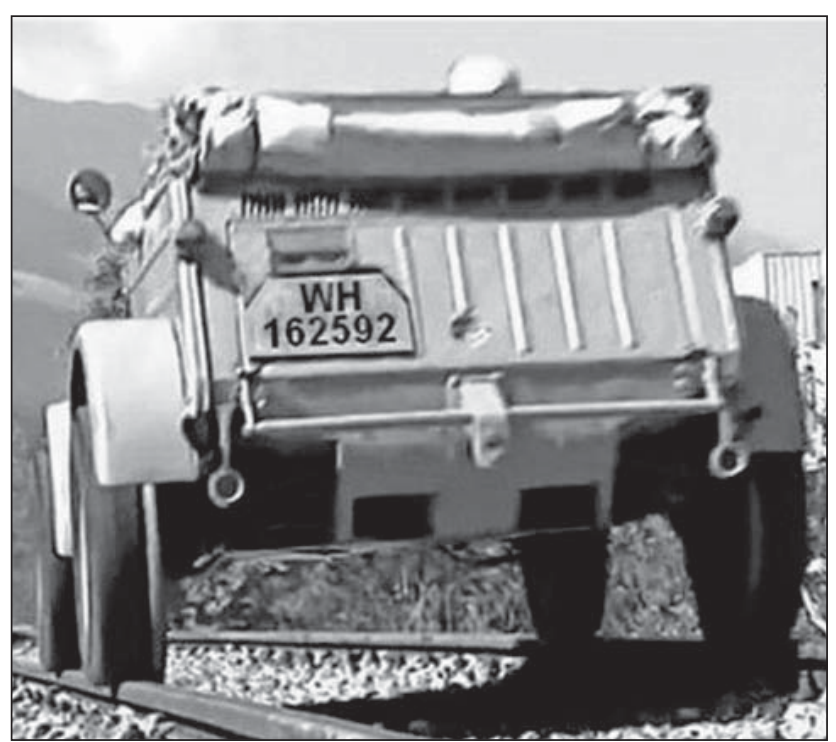

9. ábra. A képen jól látható, hogy a gumiabroncsnak csak közel a fele fekszik fel a sínfejen

A sínen történő haladás egyik fontos feltétele volt az előirt keréknyomás beállítása, és annak időszakos ellenőrzése. Ennek megkönnyítése céljából minden acéltárcsán két nyílás volt, amelyeken keresztül felszerelt kerekek - a tárcsa felé álló szelepek - esetén is kontrollálható volt a tömlőnyomás. Alacsony keréknyomás esetén váltókon vagy sínkereszteződésen áthaladáskor a nyomtárcsa felüthetett, ami a gépkocsi futóművének részeit károsította volna.

Az acéltárcsa átmérője $711 \mathrm{~mm}$, ami a gépkocsi eredeti gumiabronccsal és előírt légnyomással használatakor 27 mm-rel nyúlt a sínfej-futófelület szintje alá. A sínen történő haladáskor azonban a gumiabroncsnak csak egy része feküdt fel, ami a közúti üzemhez képest lényegesen kisebb tapadást jelentett. Ennek okán a szetthez adott használati utasítás óv a hirtelen gyorsítástól, fékezéstől és kuplungozástól is.

A kezelési szabályzat sínüzem esetén (megengedett max. sebesség $40 \mathrm{~km} / \mathrm{h}$ ) olyan kíméletes vezetést javasol, „mintha a gépkocsival jeges úton közlekednének". Minthogy a gumiabroncsoknak csak a fele feküdt fel a sínen, az egyenletes kopás érdekében a szabályzat a keréktárcsán való forgatásukat írja elő. A kormánykereket menet közben nem kellett fogni, szerepe csak a sínre fel-, vagy onnan lehajtáskor volt.

Közútra épített járművek időszakos vasúti üzeme ma is bevett gyakorlat. Különösen speciális gépkocsik, vontatók, rakodógépek üzemelnek ilyen „kétlaki” módon. Az ezt segítő berendezések általában az eredeti gumiabroncsos kerekeket kiegészítő, kisebb méretű nyomkarikás kerekek, de hosszabb sínüzem esetén a gumiabroncsos kerekek lecserélése a célszerübb. A fent leírt, a Volkswagen kocsinál alkalmazott megoldás azonban nem élt tovább. A maga idejében, abban a gépkocsi-kategóriában azonban mindenképpen életképes ötlet volt.

\section{FORRÁSMUNKÁK}

Volkswagen (Typ 82) schienengängig. Beschreibung, Umbau- und Betriebsanleitung, Ersatzteilliste 1.4.1944; Jevgenyij Procsko: Bronyeavtomobil BA-64, Cejghaus, Moszkva 2006. 